doi: 10.32620/oikit.2019.86.12

УДК 338.28

А. І. Трифонова

\title{
Аналіз існуючих моделей та інструментів управління стейкхолдерами проекту
}

\author{
Національний аерокосмічний університет ім. М. Є. Жуковського \\ «Харківський авіаційний інститут»
}

Проаналізовано існуючі інструменти і моделі управління зацікавленими сторонами проекту. Відомо, що ефективна взаємодія зі стейкхолдерами позитивно впливає на різні аспекти управління проектом. У статті акцентується увага на необхідності стейкхолдер-аналізу як невід'ємної частини проекту. Великий інтерес до даної тематики пов'язаний із тим, що кращі результати діяльності показують організації, які в процесі своєї роботи створюють цінність для всіх стейкхолдерів. Підтвердженням цьому $є$ те, що у п'ятому виданні стандарту Інституту управління проектами PMBoK, управління зацікавленими сторонами було виділено в нову самостійну галузь знань з управління проектами. Сьогодні існуючі методи і моделі призначені для рівня виконавців: керівники проекту, керуюча команда, фрахівці офрісів. Проте для верхніх ешелонів влади і управління бізнесом відповідні моделі і методи управління практично відсутні, а це рівень прийняття стратегічних рішень, від якого залежить близько 50\% успіху проектної діяльності.

В статті розглянуто теоретико-методичні підходи та моделі стейкхолдер-аналізу, що дозволяють ідентифікувати, оцінювати характеристики важливості, сили, актуальності зацікавлених сторін і залежно від цього обрати стратегію управління взаємодією з ними. Зроблено висновок про те, що існуючі методи, як правило, розглядають взаємовідносини зацікавлених сторін і компаній, але не враховують специфіку проекту. Проаналізовані моделі та інструменти умовно можна розділити на 3 категорії: кількісні, якісні та комплексні. Кількісні моделі генерують числові дані, які можна перетворити в числа. Якісні моделі виробляють нечислові дані (візуалізація). Комплексні - об'єднують в собі декілька якісних та кількісних моделей, або $є$ їх комбінацією. Крім того, кількісні моделі часто є складними математичними комплексами, які можна застосовувати лише в складі автоматизованої обчислювальної системі.

Таким чином, розроблення ефективних методів управління зацікавленими сторонами в проектах та програмах є актуальним завданням.

Ключові слова: зацікавлена сторона; проект; метод; модель; інструмент; взаємодія стейкхолдерів.

\section{Вступ}

Все більше організацій починають розуміти необхідність конструктивного діалогу із зацікавленими сторонами. Ефективна взаємодія зі стейкхолдерами позитивно впливає на різні аспекти управління проектом, в той час як ігнорування їх інтересів може призвести до значних негативних наслідків і виникнення ризиків. Оскільки в цей процес залучені практично всі підрозділи, вкрай важливо створити ефективну систему управління взаємодією зі стейкхолдерами, яка забезпечить наявність необхідних умов для досягнення стратегічних цілей проекту.

Великий інтерес до даної тематики пов'язаний із тим, що кращі результати діяльності показують організації, які в процесі своєї роботи створюють цінність для всіх стейкхолдерів. Такий підхід $€$ дуже актуальним і в управлінні проектами. Більшого успіху набувають проекти, які співвідносять свої внутрішні ресурси, можливості й цілі з потребами зовнішнього оточення і, зокрема, з інтересами зацікавлених сторін.

У п'ятому виданні стандарту Інституту управління проектами PMI - Керівництві PMBoK, - управління зацікавленими сторонами було виділено в нову са- 
мостійну галузь знань з управління проектами [1]. Питанням управління зацікавленими сторонами проектів приділено у стандарті багато уваги через їх значну роль в оцінюванні значення проекту та його результатів.

Стандарти передової практики містять базові принципи побудови ефективної взаємодії із зацікавленими сторонами. Основою серій стандартів АA1000 є базовий принцип «включеності» [2], що має на увазі прийняття до уваги інтересів і потреб усіх зацікавлених сторін (включаючи тих, хто не має можливості висловити свою думку, таких, як навколишнє середовище і майбутні покоління) на всіх етапах процесу управління.

Всі використовувані в даний час методи і моделі, включаючи широко відомі в світі методології та стандарти - PMBOK, PRINCE2, IPMA ICB, P2M, призначені для рівня виконавців: керівники проекту, керуюча команда, фрахівці офісів. Але для верхніх ешелонів влади і управління бізнесом - рівень основних стейкхолдерів - відповідні моделі і методи управління практично відсутні. Але це рівень прийняття стратегічних рішень, від якого залежить близько $50 \%$ успіху проектної діяльності, саме на ньому зосереджені всі ресурси і приймаються найважливіші рішення[3].

Зважаючи на велику кількість моделей та інструментів аналізу взаємодії зацікавлених сторін, вибір придатної моделі залишається актуальним питанням та ускладняється відсутністю прийнятних кількісних моделей.

Метою цієї статті $€$ проведення аналізу існуючих моделей та інструментів управління взаємодією зацікавлених сторін і визначення перспектив їх застосування для інноваційного проекту.

\section{Викладення основного матеріалу}

Оскільки згідно із Керівництвом знань з управління проектами PMI PMBoK стейкхолдером $€$ «особа, група або організація, яка може впливати, на яку можуть вплинути або яка може сприймати себе підданою впливу рішення, операції або результату проекту» [1], то виникає необхідність класифрікації зацікавлених сторін.

Аналіз публікацій дозволив виділити різні підходи до класифікації зацікавлених сторін. дерів:

Ньюбоулд і Луфрфман у своїх роботах [4] наводять такі категорії стейкхол-

- групи впливу, які беруть участь у фрінансуванні підприємства;

- керівні менеджери;

- службовці підприємства, зацікавлені в досягненні цілей компанії;

- економічні партнери.

$€$ велика кількість підходів до класифікації зацікавлених сторін [5-9]: первинні і вторинні; прямі і непрямі; загальні та спеціалізовані; стратегічні та етичні; нормативні, непрямі і небезпечні (пасивні) зацікавлені сторони.

A. Менделоу аналізує зацікавлені сторони залежно від їх інтересів та їх влади, відповідно здатності впливати на діяльність підприємства та бажання робити це [10]. Інтегрований показник - вплив зацікавленої сторони, визначається шляхом множення влади та інтересу.

Розширенням моделі А. Менделоу можна назвати типологію Р. Мітчелла [11]. В основі типології - три чинника: законність, значущість і терміновість, тобто юридична легітимність віддавати вказівки, сила впливу зацікавленої сторони на підприємство, мінімально необхідна швидкість відповідей на запити зацікавленої сторони. 
Відповідно до стандарту взаємодії із зацікавленими сторонами AA 1000 SES «при визначенні стейкхолдерів необхідно враховувати такі метрики, як рівень відповідальності, ступінь впливу, ступінь близькості, ступінь залежності» [2].

Теорія стейкхолдерів. Модель Р.Е. Фрімана «Взаємодії організації зі стейкхолдерами» наочно показує взаємини різних груп дійових осіб як усередині, так і навколо [12]. Взаємовідносини стейкхолдерів відображаються через схему відносин влади.

Модель являє собою графічне відображення - коло або овал, оточений різним числом інших кіл або овалів. Іх зв'язують двоноправленими стрілками, при цьому кожне коло (овал) являє собою групу стейкхолдерів. У версії моделі 2003 р. Фріман перетворив систему до п'яти внутрішніх груп стейкхолдерів і шести зовнішніх.

Управлінське тлумачення. Правове тлумачення. Філіпс до розвитку графічної моделі Фрімана запропонував використання стрілок - для позначення відносин і ненаправленої лінії - для позначення формально зафіксованих відносин [12].

Модель трьох концентричних кіл. Модель Посту, Престона Сача пропонує новий погляд на стейкхолдерів фрірми (PPS) з трьома концентричними колами, що мають ресурсну базу (внутрішнє середовище), галузеву структуру та соціально політичне середовище [12].

Модель А. Фрідмана і С. Майлса будується на основі сходів участі Арнстайна [13]. На нижчих рівнях організація просто повідомляє стейкхолдерів про прийняті рішення. На середніх рівнях - пояснення, консультації, переговори - у стейкхолдерів $€$ можливість донести свою думку до організації, хоча немає гарантії, що вона буде врахована. Високі ступені взаємодії характеризуються активною участю стейкхолдерів у корпоративному процесі прийняття рішень. Відносини з різними групами стейкхолдерів знаходяться на різних рівнях участі, залежно від їх важливості і впливу на певних стадіях життєвого циклу проекту.

Автори методики «Призма ефективності» [12] допомагають змінити системи управління і оцінити ефективність їх роботи. Призма ефективності орієнтована на основні класи зацікавлених осіб, які можуть зустрітися в будь-якому проекті. Ось питання, на які намагаються дати відповіді автори методики: 1) задоволеність зацікавлених осіб; 2) внесок зацікавлених осіб; 3) стратегії; 4) процеси; 5) можливості.

Нова категоризація стейкхолдерів. Фассін запропонував нову категоризацію, основану на раніше розглянутих групах стейкхолдерів, груп тиску і регуляторів [12].

Модель Міттчела Агле Вуда містить три чинники: легітимність, влада і терміновість [14]. Перший чинник відображає можливість стейкхолдерів давати прямі або непрямі вказівки, що стосуються діяльності компанії. Значущість визначається силою впливу стейкхолдерів на компанію. I нарешті, терміновість $€$ необхідною швидкістю реакції компанії на запити або дії сторони.

Стейкхолдери, що володіють лише однією вираженою характеристикою, $є$ прихованими; двома характеристиками - очікуваними (залежні, домінуючі, небезпечні); трьома характеристиками - визначальними. Ця методика не дозволяє визначити напрямок стратегії взаємодії, проте дозволяє проранжувати стейкхолдерів за необхідним критерієм з боку компанії.

Модель Саважа [14] оцінює ймовірність нанесення шкоди зацікавленою стороною, а також можливого потенціалу взаємовигідного співробітництва. Як- 
що потенціали як загрози, так і взаємодії великі, то пропонується використовувати стратегію переговорів.

Стратегію захисту застосовують у разі високого потенціалу загрози і низького потенціалу взаємодії. Висока готовність до співпраці і низька загроза з боку стейкхолдера - підстави для стратегії залучення. Нарешті, стратегія спостереження може бути застосована до стейкхолдерів з невисоким потенціалом кооперації і низьким потенціалом загрози.

Проведене дослідження показало, що ряд наукових праць присвячено дослідженню оцінки взаємодій стейкхолдерів. Так, у роботі В. В. Грабаря та М. М. Салмакова [15] запропоновано модель визначення значущості зацікавлених сторін із використанням середньозважених експертних оцінок влади, законності та терміновості.

Підхід авторів до аналізу зацікавлених сторін складається 3 трьох рівнів такого аналізу. Перший рівень відповідає за загальний аналіз груп зацікавлених сторін і є симбіозом підходів Г. Саважа і Р. Мітчелла.

Визначити вагу (значущість) зацікавленої сторони на карті можна за середньозваженими експертними оцінками влади, законності і терміновості (Р. Мітчелл) за такою фрормулою:

$$
\begin{aligned}
& \text { Вага (значущість) зацікавленої сторони }= \\
& =\mathrm{k} \text { Ч влада }+\mathrm{n} \text { Ч законність }+\mathrm{m} \text { Ч терміновість }
\end{aligned}
$$

- коефріцієнт k (вага критерію Влада);

- коефіцієнт n (вага критерію Законність);

- коефіцієнт m (вага критерію Терміновість).

Далі експерти команди проекту оцінюють кожен із критеріїв (влада, законність і терміновість).

Запропонований підхід дозволяє провести ефективний аналіз зацікавлених сторін проекту, наочно відбивши їх інтереси і пропонуючи стратегії взаємодії з ними.

У роботі «Карта зацікавлених сторін - інструмент аналізу оточення бізнесу» [16] С. Д. Фурта, Т. Б. Соломатіна пропонують кількісну інтегральну міру оцінювання оточення бізнесу. Карта зацікавлених сторін показує суб'єктивне уявлення лідера компанії або робочої групи про осіб, чиї інтереси зачіпаються в процесі діяльності компанії і які можуть на неї вплинути. Тут виявляються внутрішні і зовнішні стейкхолдери.

В першу чергу, виділяється область повноважень, в якій знаходяться стейкхолдери в прямому підпорядкуванні лідера або тісно з ним пов'язані. Друга область - область прямого впливу, тобто ті особи, з якими можливе пряме взаємовигідне співробітництво або переконання. Нарешті, виділяють область опосередкованого впливу, на представників якої лідер не може впливати безпосередньо. Таким чином, карта стейкхолдерів дозволяє візуалізувати потенційні ризики, які виходять з боку оточення компанії або проекту.

Таблиця інтересів стейкхолдерів. Даний інструмент застосовують частіше за все на додаток до карти стейкхолдерів [14]. У таку таблицю переносяться числові показники щодо області впливу лідера, сили підтримки / супротиву та сили впливу стейкхолдерів, а крім того, додають інформацію за інтересами стейкхолдерів, які лежать в основі оцінювання сили підтримки, і інструментів їх впливу. Такий аналіз дозволяє підтвердити спроможність отриманих експертних оцінок на етапі побудови карти зацікавлених сторін. Підсумком складання таб- 
лиці інтересів стейкхолдерів є розроблення стратегії взаємодії, основаної на розумінні його інтересів і можливих інтересів впливу на компанію.

Матриця «підтримка × сила впливу». Даний інструмент являє собою систему координат, по осях якої розташовані сила підтримки / супротиву та сила впливу і на якій відповідно до отриманих раніше результатів розміщуються стейкхолдери [14]. Така матриця дозволяє виявити, які з стейкхолдерів можуть становити найбільшу загрозу для компанії (найменша підтримка + найбільший вплив). Матриця «підтримка х сила впливу» дозволяє прояснити, на що має бути спрямована стратегія по взаємодії зі стейкхолдерами.

Інтегральна міра оціннювання оточення бізнесу - формула А. А. Пірогова. Аналітичний інструмент був розроблений для характеристики ризиків бізнесу, породжуваних людським чинником. Формула, має такий вигляд [16]:

$$
\Delta=\frac{\sum_{\text {stakeholders }} x \cdot y \cdot z}{25 \cdot \sum_{\text {stakeholders }} z}, \text { de } z=\left\{\begin{array}{l}
n, x>0 \\
0, x=0 \\
1 / n, x<0
\end{array} .\right.
$$

У наведеній вище формулі підсумовування ведеться «по всім стейкхолдерам», виключаючи самого лідера. Величина х відображає силу підтримки / протидія зацікавленої сторони, у - показує силу її впливу, a z - можливість лідера впливати на проект. Величина сили підтримки вимірюється в діапазоні від -5 до +5 , а сили впливу - від 0 до 5 . Таким чином, 25 у знаменнику - це нормуючий чинник для отримання об'єктивного результату у відсотках.

Матриці «сила - динамізм» $i$ «сила - інтерес». Інструмент дозволяє визначити, наскільки передбачуваними і стабільними можуть бути відносини з різними за силою і владою групами стейкхолдерів [14]. Найбільшу загрозу в цьому випадку являють собою зацікавлені сторони, що володіють найбільшою силою і найбільшим динамізмом.

Крім того, має сенс використовувати і другий інструмент - матрицю «сила - інтерес». Вона ранжирує стейкхолдерів за владою, якою вони володіють, і зацікавленістю в реалізації проекту або діяльності компанії.

Багатокритеріальний стейкхолдер-аналіз. Аналіз оцінює як довготривалі фрінансові витрати на реалізацію проекту, так і соціальну значущість наслідків його реалізації [14]. Даний підхід дозволяє більш чітко оцінити інтереси стейкхолдерів на стадії оцінювання і вибору проектів, а також виявити можливі конфрлікти. Якісні оцінки наслідків реалізації проекту для зацікавлених сторін ґрунтуються на експертних підходах, а пошук балансу між їхніми інтересами - на методах багатокритеріальної оптимізації.

Потім оціннюють узгодженність інтересів учасників проекту шляхом виявлення області взаємних виграшів, точки загрози, Парето ефективних рішень і узгодженого рішення, яке буде максимально можливим чином враховувати інтереси всіх стейкхолдерів.

Дж.Шевальєр і Дж. Баклес у 2008 році запропонували візуалізувати моделі стейкхолдерів. Модель «Райдуги» робить акцент на вивчення і виявлення стейкхолдерів у проблемних зонах діяльності організації [17].

Особливістю моделі $є$ перелік варіантів ідентифікації ключових стейкхолдерів (ідентифікація за допомогою експертів, інших стейкхолдерів; аналіз документації, моніторинг подій і процесів, до яких включено ті чи інші стейкхолдери). Потім пропонується занести стейкхолдерів у діаграму у вигляді веселки, яка 
класифікує їх відповідно до ступеня впливу, який здійснюється у вибраній проблемній зоні (високий, помірний, низький вплив).

Підхід SRM. Дана модель складається з чотирьох кроків. По-перше, це етап планування, на якому відбувається розроблення методології ідентифікації стейкхолдерів, розвитку відносин з ними і показників контролю і оціннювання діяльності. Другий етап - етап підготовки всіх необхідних для взаємодії ресурсів. На третьому етапі відбувається встановлення контактів зі стейкхолдерами і розроблення плану подальшої взаємодії. Нарешті, четвертий етап присвячений безпосередньо взаємодії та ії̈ вдосконаленню [12].

У роботі «Gover Handbook of Project Management» [18] наведено алгоритм впливу стейкхолдерів на різних ділянках життя проекту та запропоновано використання науково-економічного підходу до моделі оцінювання взаємодії зі стейкхолдерами.

У роботі C. Зедана та В. Міллера [19] запропоновано модель кількісної оцінки зацікавленості стейкхолдерів і ступеня їх залученості у проект. Кількісна оцінка впливу зацікавлених сторін на проект дозволяє розробити план взаємодії, який враховує різні цілі, потреби, рівні знань, авторитет, зв'язок і близькість зацікавлених сторін до процесів прийняття рішень на різних етапах проекту.

В дисертаційній роботі М. В. Рахманової [20] «Розработка методов инновационного стратегического анализа ВУЗа на основе теории заинтересованных сторон» [3] запропоновано методику розрахунку ефективності взаємодії ВН3 та його груп зацікавлених сторін. Запропоновано методичний підхід до оцінювання конкурентного потенціалу ВНЗ як стейкхолдер-компанії.

Автори Ломазов А. В., Ломазов В. A. [21] запропонували оцінювати варіанти проекту з урахуванням інтересів його учасників (стейкхолдерів).

Оцінюючи показник ступеня задоволення інтересів (СЗІ) кожного стейкхолдера St результатами реалізації вже здійснюваного або тільки планованого проекту Ind (St), неможливо обійтися без залучення незалежних експертів, які висловлюють свої судження, як правило, вербально. Автори вважають, що Ind (St) являє собою кортеж з трьох значень:

$$
\operatorname{Ind}(\mathrm{St})=<\operatorname{Indabs}(\mathrm{St}), \operatorname{Indverb}(\mathrm{St}) \text {, Indrel }(\mathrm{St})>,
$$

де Indabs (St) - абсолютне числове (якщо воно є) значення, виражене в змістовних одиницях виміру; Indverb (St) - вербальне (виражене в словесних термінах) значення; Indrel (St) - відносне числове (виражене, наприклад, у балах) значення показника Ind (St). При цьому для кожного показника задається свій тривимірний (отриманий в результаті декартового перемноження) домен можливих значень D (St) = Dabs $(\mathrm{St}) \times \operatorname{Dverb}(\mathrm{St}) \times$ Drel $(\mathrm{St})$ і розробляються експертами шкали відповідності між значеннями різних типів.

Поєднання оптимістичної і песимістичної стратегії (аналог зваженого критерію Гурвіца) реалізується відповідно до правила:

$$
\operatorname{Ind}^{r e l}\left(S t_{i j}\right)=(1-\gamma) \min \operatorname{Ind}^{r e l}(S t)_{i j}+\gamma_{i j} \max \operatorname{Ind}^{r e l}(S t)_{i j} .
$$

Автори О. В. Гайдаєнко, К. В. Кошкін відзначають, що успішність проектів великою мірою визначається споживачами. Тому нагальною потребою є визначення проектного оточення, учасників або стейкхолдерів проектів, їх внесок до успішності або провалу проекту, набуття цінностей його учасниками, задоволення їх очікувань [22]. Запропоновано два підходи до управління стейкхолдерами: 
1. Партнерський підхід, оснований на тому, щоб зав'язати з усіма стейкхолдерами партнерські відносини, заручитися підтримкою і довірою.

2. Метод захисту, який передбачає, що стейкхолдери в певний момент можуть зробити негативний вплив на компанію, тому необхідно бути готовим до такої ситуації. Готовність означає всебічний аналіз стейкхолдерів.

Автори О. В. Логіновській, Я. Д. Гельруд запропоновали укрупнену інформаційно-логічну схему взаємодії стейкхолдерів [3]. Алгоритм інтеграції математичних моделей і методів для реалізації управління проектом складається 3 процедур агрегування мережних моделей. Для кожного рівня управління і кожного стейкхолдера визначені необхідні типи мережних моделей, їх параметри і методи оброблення. Де: ДСМ (Детальна мережна модель) - для команди управління проектом, проектного офрісу; ІФМ (Інвестиційно-фрінансова модель) для Інвестора; ПСМ (Приймально-здавальна модель) - для Замовника; УСМ (Узагальнена мережна модель) - для Генерального підрядника; ОЛМ (Операційно-логістична модель) - для Постачальника; МІВП (Модель виконання владних повноважень) - для регулюючих і наглядових органів, органів влади; ДМ (Дохідна модель) - для комерційної служби.

Загальна математична модель інтегрованої інформаційно-аналітичної системи управління проектами виглядає таким чином:

$$
\mathrm{Qi}(Д \mathrm{C} M)=\mathrm{Gi}(\mathrm{i}=1,2, \ldots, 6),
$$

де Qі - оператори агрегування детальної мережної моделі,

$$
\mathrm{Gi}=(I \Phi M \vee \Pi C M \vee У C M \vee O Л M \vee M И В \Pi \vee Д M) ; \operatorname{Ri}(\mathrm{Gi}),
$$

де $\mathrm{Ri}$ - оператори формування плану, оптимального за критеріями i-го стейкхолдера, відповідно до властивих йому комплексів математичних моделей,

$$
Q_{i}^{-1}\left[R_{i}\left(G_{i}\right)\right]=Д C M^{\prime},
$$

де $Q_{i}^{-1}$ - оператори зворотного агрегування мережної моделі для і-го стейкхолдера. Часто одна і та ж компанія може виступати в двох і більше ролях стейкхолдерів, якщо n - число стейкхолдерів, то $C_{n}^{k}$ - число різних комбінацій з n по k:

$$
\sum_{k=0}^{n} C_{n}^{k} \sum_{i=0}^{n-k} C_{n-k}^{i}=\sum_{k=0}^{n} C_{n}^{k} \cdot 2^{n-k}=(1+2)^{n}=3^{n}
$$

При п'яти стейкхолдерах отримуємо $3^{5}=243$ варіантів різних сполучень. Таким чином, має бути забезпечена можливість для автоматизованого поєднання окремих моделей управління і створення комбінованих моделей.

Модель вибору стратеаії взаємодії із зацікавленою стороною запропонована авторами [23]. Для побудови моделі вибору стратегії компанії щодо взаємодії з її зацікавленою стороною на певному етапі життєвого циклу розвитку компанії, всі зацікавлені сторони компанії можуть бути записані у вигляді формули:

$$
S=\left(S_{1}, S_{2}, \ldots S_{n}\right),
$$

де $S$ - всі стейкхолдери проекту, $n$ - їхня кількість. Розглянемо формування стратегії взаємодії із групою стейкхолдерів $S 1$. Витрати ресурсів компанії на формування однієї з «дружніх» стратегій взаємодії - бріджінгу або партнерства (зі стейкхолдерами S1), можуть бути наведені у вигляді фрормули:

$$
R_{\text {об }}=R_{1}+R_{2}+\ldots+R_{m}
$$


де Roб - загальні витрати різних видів ресурсів на реалізацію даної стратегії; $R 1$ - витрати першого ресурсу компанії на реалізацію стратегії, $R 2$ - другого і т.д.; $m$ - загальна кількість витрачених ресурсів на реалізацію даної стратегії. В результаті реалізації вибраної «дружної» стратегії взаємодії зі стейкхолдерами S1 компанією можуть бути отримані (або не отримані) певні ресурсні вигоди в короткостроковій або довгостроковій перспективі.

Ресурсні вигоди, отримані компанією при реалізації даної стратегії взаємодії зі стейкхолдерами S1, можуть бути подані у вигляді фоормули:

$$
V_{\text {об }}=V_{1}+V_{2}+\ldots+V_{i}
$$

де Voб - загальні ресурсні вигоди, одержувані компанією від реалізації даної стратегії взаємодії зі стейкхолдерами S1; V1 - ресурсні вигоди за першим ресурсом; V2 - за другим, і т.д.; $i$ - загальна кількість видів ресурсів, за якими можуть бути отримані вигоди від взаємодії з даним стейкхолдером. Після виконання оцінки витрат ресурсів і одержуваних ресурсних вигод від застосування стратегії взаємодії зі стейкхолдерами S1, слід порівняти значення Roб і Voб. Якщо:

$$
R_{\text {об }} \leq V_{\text {об }},
$$

то розглянута стратегія $є$ вигідною для компанії в рамках ресурсного обміну з даними стейкхолдерами S1 та може бути прийнята до реалізації. Якщо, навпаки:

$$
R_{\text {об }}>V_{\text {об }}
$$

то слід розглянути інші варіанти стратегій взаємовідносин зі стейкхолдерами $S 1$ за даною методикою. При цьому порядок розгляду стратегій обирають від найбільш «дружніх» через нейтральні до «захисних».

I. В. Чумаченко пропонує використовувати порівняння ієрархічної структури робіт проекту (WBS) з такими іерархічними структурами [24]:

- $R$ (equirement)BS - ієрархічна структура вимог проекту;

- $R$ (isk)BS - ієрархічна структура ризиків проекту;

- $R$ (esource)BS - ієрархічна структура ресурсів проекту;

- $R$ (esponsibility)BS - організаційна структура проекту.

Таким чином, встановлюються відповідності «робота-вимога», «роботаресурс», «робота-відповідальний», «робота-ризик». Математично зазначені взаємозв'язки формулюються через матриці контрольних точок.

Матриці контрольних точок будуються для відображення взаємозв'язків «робота-вимога», «робота-ресурс», «робота-відповідальний», «робота-ризик» («work-requirement», «work-resource», «work-responsibility», «work-risk»):

$$
\sum_{i=1}^{n} m_{i j} \geq 1, \sum_{i=1}^{k} m_{i j} \geq 1
$$

Для кожного рядка та стовпця матриці контрольних точок невиконання умов свідчить про наявність помилок у встановленні взаємозв"язків (наприклад, певна робота не пов'язана з виконанням жодної вимоги та навпаки). Закріплення певних характеристик проекту за окремими його роботами дозволить відстежувати їх виконання у динаміці.

B. В. Іллюк зазначає, що при дослідженні проблем взаємин зацікавлених сторін інноваційних проектів і цінностей стейкхолдерів $€$ необхідність реалізації механізму ідентифікації, оцінювання, методології роботи і розподілу значущості серед стейкхолдерів [25].

Неврівноваженість таких об'єднань, реалізація наукоємних інноваційних проектів потребує залучення всіх або частини ресурсів від різних зацікавлених 
осіб. Лише домовившись між собою і об'єднавшись в групи за інтересами (науково-виробничі кластери), стейкхолдери мають шанси на успіх проекту.

Авторами у роботі [26] запропоновано модель класифрікації залучених стейкхолдерів і модель взаємодії зацікавлених сторін проекту. Модель являє собою схему зв'язків між стейкхолдерами та відображення рівня їх впливу на проект. Радіус кіл, відповідних кожному стейкхолдеру, свідчить про величину його впливу. Для побудови моделі був застосований системний підхід, при якому стейкхолдерів було розглянуто як цілісний комплекс взаємозв'язаних елементів.

Структуризація наведеної моделі дозволяє аналізувати взаємодію стейкхолдерів проекту. Так, можна чітко виділити зовнішніх і внутрішніх стейкхолдерів. Існує центральний внутрішній стейкхолдер (наприклад, керівник проекту) $\mathrm{St}_{1}{ }^{\text {внутр }}$, який має прямі зв'язки з усіма іншими стейкхолдерами, які, в свою чергу, пов'язані між собою потенційними зв'язками. Як внутрішні, так і зовнішні стейкхолдери можуть мати або прямі зв'язки, або ж взаємодіяти через центрального стейкхолдера. Зовнішні зацікавлені сторони взаємодіють з внутрішніми тільки за допомогою прямого зв'язку з центральним внутрішнім стейкхолдером $\mathrm{St}_{1}{ }^{\text {внтр }}$.

Крім того, автори у роботі [27] пропонують метод кількісної оцінки взаємодії стейкхолдерів шляхом розрахунку значення ключових показників, таких, як внесок і стимул. Запропоновано модель для аналізу збалансованості цих показників. Модель дозволяє будувати діаграми збалансованості, які відображають дисбаланс взаємодії зацікавлених сторін.

Запланований внесок стейкхолдера розраховують за фрормулою:

$$
\begin{aligned}
& A_{i, j}=\frac{V_{i, j, 1}^{A} \cdot C_{i, j, 1}^{A}+V_{i, j, 2}^{A} \cdot C_{i, j, 2}^{A}+\ldots+V_{i, j, g}^{A} \cdot C_{i, j, g}^{A}}{P_{i, j-1}^{A}}+C_{i, j}^{a d d}= \\
& =\frac{\sum_{l=1}^{g} V_{i, j, l}^{A} \cdot C_{i, j, l}^{A}}{P_{i, j-1}^{A}}+C_{i, j}^{a d d}=\frac{\sum_{l=1}^{g} A_{i, j, l}}{P_{i, j-1}^{A}}+C_{i, j}^{a d d},
\end{aligned}
$$

де $A_{i, j}$ - очікуваний «внесок» і-го стейкхолдера на ј-му етапі; $A_{i, j, l}$ - внесок стейкхолдера в межах одного зв'язку, $\mathrm{C}^{\mathrm{A}}$ - грошовий еквівалент складової внеску; $V^{A}$ - показник цінності внеску в зв'язку , n - кількість зв'язків; $P^{A}{ }_{i, j-1}-$ показник виконання зобов'язань за внеском і-го стейкхолдера на попередньому етапі; $\mathrm{C}^{\text {add }}$ додаткова складова внеску.

Тепер розглянемо визначення величини очікуваного стимулу «К», використовуючи формулу:

$$
\begin{aligned}
& K_{i, j}=\frac{V_{i, j, 1}^{K} \cdot C_{i, j, 1}^{K}+V_{i, j, 2}^{K} \cdot C_{i, j, 2}^{K}+\ldots+V_{i, j, g}^{K} \cdot C_{i, j, g}^{K}}{P_{i, j-1}^{K}}+C_{i, j}^{\text {bonus }}= \\
& =\frac{\sum_{l=1}^{g} V_{i, j, l}^{K} \cdot C_{i, j, l}^{K}}{P_{i, j-1}^{K}}+C_{i, j}^{\text {bonus }}=\frac{\sum_{l=1}^{g} K_{i, j, l}}{P_{i, j-1}^{K}}+C_{i, j}^{\text {bonus }},
\end{aligned}
$$

де $K_{i, j}$ - очікуваний стимул і-го стейкхолдера на ј-му етапі; $K_{i, j, l}$ - стимул стейкхолдера в межах одного зв'язку; $\mathrm{C}^{\mathrm{K}}$ - грошовий еквівалент складової стимулу; 
$V^{K}$ - показник цінності стимулу в зв'язку; $P^{K}{ }_{i, j-1}-$ показник рівня досягнення поставленої мети і-го стейкхолдера на попередньому етапі; c $^{\text {bonus }}$ - додаткова стимулююча складова.

Співвідношення «К» і «А» - це важливий показник взаємодії стейкхолдера з іншими зацікавленими сторонами, оскільки він $€$ показником збалансованості «f» системи взаємодії. Збалансованість показників - це рівновага між різними показниками, що допомагають визначити ефективність.

У межах одного етапу інноваційного проекту показник збалансованості взаємодії стейкхолдера з іншими зацікавленими сторонами можна визначити, використовуючи формулу:

$$
f_{i, j}=\frac{K_{i, j}}{A_{i, j}}=\frac{K_{i, j, 1}+K_{i, j, 2}+\ldots+K_{i, j, g}}{A_{i, j, 1}+A_{i, j, 2}+\ldots+A_{i, j, g}}=\frac{\sum_{l=1}^{g} K_{i, j, g}}{\sum_{l=1}^{g} A_{i, j, g}},
$$

де $i=1 \ldots n-$ номер стейкхолдера, $j=1 \ldots m$ - номер етапу; $l=1 \ldots g-$ кількість зв'язків на етапі; А - внесок, К - стимул.

Формула для визначення сумарної збалансованості взаємодії стейкхолдера з іншими зацікавленими сторонами проекту на всіх етапах матиме вигляд:

$$
f_{i}^{\text {total }}=\frac{K_{i}}{A_{i}}=\frac{K_{i, 1}+K_{i, 2}+\ldots+K_{i, m}}{A_{i, 1}+A_{i, 2}+\ldots+A_{i, m}}=\frac{\sum_{j=1}^{m} K_{i, j}}{\sum_{j=1}^{m} A_{i, j}},
$$

де $K_{i}$ та $\mathrm{A}_{i}$ - сумарний внесок і стимул відповідно.

I. В. Ремешевська пропонує спочатку для визначення категорій зацікавлених сторін використати матрицю вплив / інтерес [28]. Для того, щоб визначити вплив різних стейкхолдерів на діяльність організації, використовують рангову діаграму учасників корпоративних відносин. Для побудови матриці зацікавлених сторін користуються середньозваженими експертними оцінками. Прийнято, що сумарна вага критеріїв «рівень зацікавленості (Int)» та «ступінь впливу (Еff)» становить $100 \%$, у тому числі: коефріцієнт $\alpha-60 \%$, коефіцієнт $\beta-40 \%$. Значення індексів лежать в інтервалі від 0 до 2, значущими є індекси більше 1. Матриця розбита на чотири квадранти, радіус кола дорівнює числовому значенню, розрахованому за формулою:

$$
\text { imp } p_{\text {sth }}=\text { Eff } \cdot \alpha+\operatorname{Int} \cdot \beta
$$

де Eff - ступінь впливу; Int - рівень зацікавленості; $\alpha, \beta$ - коригуючі коефріцієнти.

Для визначення профілів зацікавлених сторін проектів скористаємося формулою:

$$
\text { wei }=k \cdot e s s+n \cdot c o m+m \cdot r e s,
$$

де ess - рівень суттєвості; com - рівень повноти; res - ступінь реагування; $k, n$, $m$ - коригуючі коефіцієнти. Також приймаємо, що сумарна вага критеріїв, рівень суттєвості (ess), рівень повноти (com) і ступінь реагування (res) становлять $100 \%$. 
Для чіткого розуміння який інструмент, метод чи модель більш придатний для рішення питання, як саме управляти взаємодією стейкхолдерів інноваційного проекту, пов'язаного з модернізацією обладнання на підприємстві, був зроблений детальний аналіз. Інструменти, які розглянуті в статі, на нашу думку $є$ сучасними та найчастіше обговорюється науковцями у сфері управління проектами та програмами.

Проаналізовані моделі та інструменти умовно можна розділити на 3 категорії: кількісні, якісні та комплексні. Кількісні моделі генерують числові дані, які можна перетворити в числа. Якісні моделі виробляють нечислові дані (візуалізація). Комплексні - об'єднують в собі декілька якісних та кількісних моделей, або є їх комбінацією. Результат класифікації представлено в таблиці 1.

Класифрікація методів та інструментів управління

Таблиця 1 взаємодією зацікавлених сторін

\begin{tabular}{|c|c|c|}
\hline Якісні & Кількісні & Комплексні \\
\hline $\begin{array}{l}\text { Теорія стейкхолдерів. } \\
\text { Модель Р.Е. Фрімана [12]. }\end{array}$ & Модель А.Менделоу. [10] & $\begin{array}{l}\text { Модель В.В. Грабаря, М.М. } \\
\text { Салмакова [15] }\end{array}$ \\
\hline $\begin{array}{l}\text { Управлінське тлумачення. } \\
\text { Правове тлумачення Філіпса } \\
\text { [12]. }\end{array}$ & $\begin{array}{l}\text { Інтегральна міра оцінювання. } \\
\text { Формула Пирогова А.А. [16] }\end{array}$ & $\begin{array}{l}\text { Багатокритеріальний стейк- } \\
\text { холдер-аналіз [14] }\end{array}$ \\
\hline $\begin{array}{l}\text { Модель трьох концентричних } \\
\text { кіл. Модель Посту, Престона, } \\
\text { Сача [12]. }\end{array}$ & $\begin{array}{l}\text { Модель С. Зедана та В. Міл- } \\
\text { лера [19] }\end{array}$ & $\begin{array}{l}\text { Научно-экономічний підхід } \\
\text { [18] }\end{array}$ \\
\hline $\begin{array}{l}\text { Модель А. Фрідмана і С. } \\
\text { Майлса [13]. }\end{array}$ & Модель М.В. Рахманової [20] & $\begin{array}{l}\text { Модель } \\
\text { І.В. Ремешевської та Н.В. } \\
\text { Гурець. [28] }\end{array}$ \\
\hline Призма ефрективності [12] & $\begin{array}{l}\text { Модель Ломазова А.В. та } \\
\text { Ломазова В.А. [21] }\end{array}$ & $\begin{array}{l}\text { Модель О.В. Логіновського, } \\
\text { Я.Д. Гельруда [3] }\end{array}$ \\
\hline $\begin{array}{l}\text { Модель Миттчела Агле Вуда } \\
\text { [14] }\end{array}$ & $\begin{array}{l}\text { Модель стратегії взаємодії } \\
\text { стейкхолдерів [23] }\end{array}$ & Підхід SRM [12] \\
\hline Модель Г. Саважа [14] & Модель І.В. Чумаченко [24] & $\begin{array}{l}\text { Модель класифрікації залуче- } \\
\text { них стейкхолдерів і модель } \\
\text { взаємодії зацікавлених сторін } \\
\text { інноваційного проекту [26] }\end{array}$ \\
\hline $\begin{array}{l}\text { «Карта зацікавлених сторін» } \\
\text { С.Д. Фурта, Т.Б. Соломатіна } \\
\text { [16] }\end{array}$ & & $\begin{array}{l}\text { Метод кількісної оцінки взає- } \\
\text { модії стейкхолдерів шляхом } \\
\text { розрахунку значення ключо- } \\
\text { вих показників [27] }\end{array}$ \\
\hline \multicolumn{3}{|l|}{$\begin{array}{l}\text { Таблиця інтересів стейкхол- } \\
\text { дерів [14] }\end{array}$} \\
\hline \multicolumn{3}{|l|}{$\begin{array}{l}\text { Матриця «підтримка-сила } \\
\text { впливу» [14] }\end{array}$} \\
\hline \multicolumn{3}{|l|}{$\begin{array}{l}\text { Матриця «сила - дінамізм», } \\
\text { «сила-інтерес» [14] }\end{array}$} \\
\hline \multicolumn{3}{|l|}{$\begin{array}{l}\text { Модель «Райдуга» Дж. Ше- } \\
\text { вальєр та Дж. Баклес [17] }\end{array}$} \\
\hline \multicolumn{3}{|l|}{$\begin{array}{l}\text { Модель О.В. Гайденко, К.В. } \\
\text { Кошкіна [22] }\end{array}$} \\
\hline \multicolumn{3}{|l|}{ Модель В.В. Іллюка [25] } \\
\hline Модель Фассіно [12] & & \\
\hline
\end{tabular}




\section{Висновки}

Проведений аналіз інструментів управління взаємодією стейкхолдерів показав, що існуючі методи і моделі, як правило, розглядають взаємовідносини зацікавлених сторін і компаній, але не враховують специфіку проекту, тобто запропоновані інструменти не завжди придатні для проектного менеджменту. Таким чином, розроблення ефективних методів управління зацікавленими сторонами при управлінні інноваційними проектами та програмами є актуальним завданням.

Сьогодні можна знайти різні підходи до управління стейкхолдерами, проте науковці в основному роблять акцент на інструментах якісного аналізу та візуалізації, а не на кількісних моделях. Отже, застосовуючи такий підхід, ми лише бачимо візуалізацію існуючих зв'язків. В той же час запропоновані кількісні моделі часто $є$ складними математичними комплексами, які можна застосовувати лише в складі автоматизованої обчислювальної системі. При цьому необхідність управління відносинами зі стейкхолдерами об'єктивно існує. Для вирішення проблеми потрібно розробити цілісну методологію, базисом якої буде визначення та класифікація стейкхолдерів. Такі моделі управління взаємовідносинами із зацікавленими групами і механізми оцінювання ефективності цього управління не отримали ще відповідного системного розвитку.

Вирішення завдання управління стейкхолдерами в інноваційних проектах потребує особливої відповідальності, тому що це пов'язано з великими ризиками, капіталовкладеннями, складністю реалізації, наукоємністю і т.д. Для проектів, властивих інновації, необхідний зрозумілий, чіткий і, головне, такий, що реалізується алгоритм управління стейкхолдерами.

Таким чином, розроблення нових моделей і методів, які можна застосувати як в теорії, так і на практиці, дозволять чітко позначати роль і внесок кожного з учасників відносин і, відповідно, вибудовувати ефективні комунікації, ставити конкретні завдання перед менеджментом і контролювати їх реалізацію.

\section{Література}

1. A Guide to the Project Management Body of Knowledge (PMBOK® Guide) [Text]. - Fifth Edition. - Project Management Institute, 2013. - $589 \mathrm{p}$

2. AA 1000 AccountAbility Principles Standard 2008 [Електронний ресурс]. Режим доступа: http://www.accountability.org/images/content/0/7/074/AA1000APS\%202008.pdf

3. Логиновский, О.В. Информационно-аналитическая система управления проектами на базе использования комплекса математических моделей функционирования стейкхолдеров / О.В. Логиновский, Я.Д. Гельруд // Вестник ЮУрГУ. Серия «Компьютерные технологии, управление, радиоэлектроника». - 2015. T. 15, № 3. - C. 133 - 141. DOI: 10.14529/ctcr150316

4. Попов, С. А. От теории стейкхолдеров - к реализации концепции общих ценностей [Текст] / С. А. Попов, Л. Л. Фомина // Российское предпринимательство. - 2013. - № 2 (224). - С. 60-65.

5. Freeman, R. Edward, Tensions in Stakeholder Theory. [Text] / R. Edward Freeman, R. Phillips, R. Sisodia // Business \& Society. - 2018. - 19 p.

6. Freeman, R. Edward. Corporate Social Responsibility and Stakeholder Theory: Learning From Each Other [Text] / R. Edward Freeman, S. Dmytriyev // SYMPHONYA Emerging Issues in Management. - 2017. - pp. 7-15. 
7. Bridoux, F., Stakeholde rrelationships and social welfare: A behavioral theory of contributions to joint value creation [Text] / F. Bridoux, J. W. Stoelhorst // Academy of Management Review.- 2016. - No. 41. - Pp. 229-251.

8. Freeman, R. Edward, Stakeholder theory. Thestate of the art. [Text] / Freeman R. Edward, Harrison J.S., Wicks A.C., Parmar B.L., De Colle S. // New York: Cambridge University Press. - 2010. - Vol. 4, No. 1. - Pp. 403-445.

9. Keevil, A.A. Behavioral stakeholder theory [Text]: PhD Thesis / A.A. Keevil //. Charlottesville: University of Virginia. - 2014. - 127 p.

10. Mendelow, A. Stakeholder Mapping [Text] / A. Mendelow // Proceedings of the 2nd International Conference on Information Systems. Cambridge, MA. - 1991. pp.18-23.

11. Mitchell, R. Theory of Stakeholder Identification and Salience: Defining the Principle of Who and What Really Counts [Text] / R.K. Mitchell, B.R. Agle, D.J. Wood A. Toward // Academy of Management Review. - 1997. - Vol. 22, № 4. - P. 853-888.

12. Белоконь, А. И. Теоретические аспекты определения и взаимодействия заинтересованных групп лиц в проектах [Текст] / А. И. Белоконь, С. А. Маланчий, Т. А. Алкубалайт // Вісник Придніпровської державної академії будівництва та архітектури. - 2016. - № 1 (214), - С. $72-78$

13. Friedman, L. Stakeholders Theory and Practice [Text] / L. Friedman, S. Miles // Oxford University Press - 2006.

14. Санталова, М.С. Сравнительный анализ подходов к оценке инвестиционных проектов с учетом интересов стейкхолдеров [Текст] / М.С. Санталова, А.А. Уланов // Экономика и управление предприятием. - 2017 г. - №5. - С.1 -11.

15. Грабарь, В. В. Анализ заинтересованных сторон проекта: методология, методика, инструменты [Электронный ресурс] / В. В. Грабарь, М. М. Салмаков // ARS ADMINISTRANDI. - 2014. - № 2. - С. 36-44. - Режим доступа: http:// arsadministrandi.com/article/Grabar_Salmakov_2014_2.pdf. - 12.05.2015

16. Фурта, С.Д. Карта заинтересованных сторон - инструмент анализа окружения бизнеса [Текст] / С.Д. Фурта, Т.Б. Соломатина // Инициативы XXI века. - 2010. - №1. - С.22-27.

17. Chevalier, J.M. SAS2: a Guide to Collaborative Inquiry and Social Engagement [Text] / J.M. Chevalier, D.J Buckles // Sage Publications. - 2008. - .193-254.

18. Rodney, Turner J.. Gower Handbook of Project Management: 4th Editione. Gower e-book [Text] / Turner J Rodney.- 2007. - 912 p.

19. Zedan, S. Quantifying stakeholders' influence on energy efficiency of housing: development and application of a four-step methodology [Text] / S. Zedan, W. Miller. // Construction Management and Economics. - 2018. -Vol. 36, No. 7. - Pp. 375-393.

20. Рахманова, М. С. Разработка методов инновационного стратегического анализа вуза на основе теории заинтересованных сторон [Текст] : дис. канд. ек. наук : 08.00.05 / Рахманова Марина Сергеевна - Владивосток, 2009. - 236 с.

21. Ломазов А.В. Стейкхолдер-анализ инновационных агропроектов [Текст] / Ломазов А.В., Ломазов В.A // Fundamental Research. - 2017 г. - № 9. - C.200-205.

22. Гайденко, О.В. Стейкхолдери медичних проектів [Текст] /Гайденко, О.В., Кошкин К.В.// Управління проектами та розвиток виробництва. - 2016. №2(58). - C. 12-18.

23. Рибак, А. І. Управління зацікавленими сторонами в проектному менеджменті : монографія. / А. І. Рибак, І. Б. Азарова. - Одеса : ОДАБА, 2017. - 145 c. ISBN 978-617-7195-42-8 
24. Матрична модель 4R \& WS для класифрікації стейкхолдерів проекту [Текст] / Ю. Ю. Гусєва, О. С. Мартиненко, І. В. Чумаченко // Вісник НТУ «ХПІ». Серія: Стратегічне управління, управління портоелями, програмами та проектами. - Х. : НТУ «ХПІ», 2017. - № 2 (1224). - С. 17-22.

25. 13. Ильюк, В.В. Методологический подход к управлению стейкхолдерами инновационных проектов [Текст] / Организатор производства.- 2016. - № 4.- C. $38-55$.

26. Трифонов, А.И. Розрахунок ключових показників моделі ASC для визначення взаємодії стейкхолдерів в інноваційному проекті [Текст] / А.І.Трифонова, Н.В. Доценко // Комунальне господарство міст. - 2019. - Т.3 (149). - С. 91 - 98

27. Трифронова, А.І. Розробка моделі для аналізу взаємодії стейкхолдерів інноваційного проекту [Текст] / А.І. Трифонова, Н.В. Доценко // Вчені записки Таврійського національного університету ім. В.І. Вернадського. - 2019. - Том 30 (69) No 2. - C. 220-225.

28. Ремешевська І. В., Гурець Н. В. Ідентифікація стейкхолдерів проектів впровадження системи екологічного менеджменту у муніципальних утвореннях // Ремешевська І. В., Гурець Н. В. // Стратегічне управління, управління портфрелями, програмами та проектами.-2019. -№ 1 (1326). - С. 63-70.

\section{References}

1. A Guide to the Project Management Body of Knowledge (PMBOK® Guide). Fifth Edition. Project Management Institute. Publ., 2013, $589 \mathrm{p}$

2. AA 1000 AccountAbility Principles Standard 2008. Available at: http://www.accountability.org/images/content/0/7/074/AA1000APS\%202008.pdf

3. Loginovskij, O.V., Gel'rud, Ja.D. Informacionno-analiticheskaja sistema upravle-nija proektami na baze ispol'zovanija kompleksa matematicheskih modelej funkcionirovanija stejkholderov [Information and analytical project management system based on the use of a complex of mathematical models of the functioning of stake holders ] Vestnik JuUrGU. Serija "Komp'juternye tehnologii, upravlenie, radiojelektronika». 2015, vol. 15, no 3, pp. 133 - 141. doi: 10.14529/ctcr150316

4. Popov, S. A., Fomina, L. L. Ot teorii stejkholderov $-\mathrm{k}$ realizacii koncepcii ob-shhih cennostej [From stakeholder theory to implementing the concept of shared values]. Rossijskoe predprinimatel'stvo. 2013, no 2 (224), pp. 60-65.

5. Freeman, R. Edward, Sisodia, R. Tensions in Stakeholder Theory. Business \& Society. 2018, $19 \mathrm{p}$.

6. Freeman, R. Edward, Dmytriyev, S. Corporate Social Responsibility and Stakeholder Theory: Learning From Each Other. SYMPHONYA Emerging Issues in Management. 2017, pp. 7-15.

7. Bridoux, F., Stoelhorst, J. W. Stakeholde rrelationships and social welfare: A behavioral theory of contributions to joint value creation. Academy of Management Review. 2016, no. 41, pp. 229-251.

8. Freeman, R. Edward, Harrison, J.S., Wicks, A.C., Parmar, B.L., De Colle, S Stakeholder theory. The state of the art. New York: Cambridge University Press.Publ. 2010, vol. 4, no. 1, pp. 403-445.

9. Keevil, A.A. Behavioral stakeholder theory: PhD Thesis Charlottesville: University of Virginia.Publ. 2014, 127 p. 
10. Mendelow, A. Stakeholder Mapping Proceedings of the 2nd International Conference on Information Systems. Cambridge, MA. 1991, pp.18-23.

11. Mitchell, R., Agle, B.R., Wood D.J., Toward, Mitchell, R.K. A.Theory of Stakeholder Identification and Salience: Defining the Principle of Who and What Really Counts. Academy of Management Review. 1997, vol. 22, no 4, pp. 853-888.

12. Belokon', A. I., Malanchij, S. A., Alkubalajt T. A. Teoreticheskie aspekty opredelenija i vzaimo-dejstvija zainteresovannyh grupp lic v proektah [Theoretical aspects of the definition and interaction of stakeholder groups in projects]. Visnik Pridniprovs'koï derzhavnoï akademiï budivnictva ta arhitekturi. 2016, no 1 (214),pp. $72-78$

13. Friedman, L., Miles, S. Stakeholders Theory and Practice. Oxford University Press. 2006, .362 p.

14. Santalova, M.S., Ulanov, A.A. Sravnitel'nyj analiz podhodov k ocenke investicionnyh proektov s uchetom interesov stejkholderov [Comparative analysis of approaches to the assessment of investment projects taking into account the interests of stakeholders]. Jekonomika i upravlenie predprijatiem. 2017, no. 5, pp.1-11.

15. Grabar', V. V., Salmakov, M. M. Analiz zainteresovannyh storon proekta: metodologija, metodika, instrumenty [Analysis of project stakeholders: methodology, methodology, tools]. ARS ADMINISTRANDI. 2014. no 2, pp. 36-44. Available at: http://ars-administrandi.com/article/Grabar Salmakov 2014 2.pdf

16. Furta, S.D., Solomatina, T.B. Karta zainteresovannyh storon instrument analiza okruzhenija biznesa [Stakeholder Map - Business Environment Analysis Tool]. Iniciativy XXI veka. 2010, no. 1, pp. 22-27.

17. Chevalier, J.M., Buckles, D.J., Chevalier, J.M. SAS2: a Guide to Collaborative Inquiry and Social Engagement. Sage Publications. 2008, pp.193-254.

18. Rodney, Turner J.. Gower Handbook of Project Management: 4th Editione. Gower e-book. 2 Rodney Turner and the contributors. Publ. 2007, 912 p.

19. Zedan, S., Miller, W. Quantifying stakeholders' influence on energy efficiency of housing: development and application of a four-step methodology. Construction Management and Economics. 2018, vol. 36, no. 7, pp. 375-393.

20. Rahmanova, M. S. Razrabotka metodov innovacionnogo strategichesko-go analiza vuza na osnove teorii zainteresovannyh storon: dis. kand. ek. nauk : 08.00.05 [Development of innovative strategic analysis methods of a university based on stakeholder theory: dis. cand. ek. sci: 08.00.05]. Vladivostok, 2009, 236 p.

21. Lomazov A.V., Lomazov, V.A Stejkholder-analiz innovacionnyh agroproektov [Stakeholder analysis of innovative agricultural projects]. Fundamental Research. 2017,no. 9, pp. 200-205.

22. Gajdenko, O.V., Koshky`n, K.V Stejkxoldery medy`chny`x proektiv [Stakeholders of medical projects]. I Upravlinnya proektamy' ta rozvy'tok vy'robny'cztva. 2016, no. 2(58), pp. 12-18.

23. Ry`bak, A. I., Azarova, I. B. Upravlinnya zacikavleny`my` storonamy` $v$ proektnomu mene-dzhmenti : monografiya. [Stakeholder management in project management: a monograph]. Odesa : ODABA. Publ. 2017, 145p. ISBN 978-6177195-42-48

24. Gusyeva, Yu. Yu., Marty`nenko, O. S., Chumachenko I. V. Matry`chna model $4 \mathrm{R}$ \& WS dlya klasy` fikaciyi stejkxolderiv proektu [Matrix model 4R \& WS for the classification of project stakeholders]. Visny 'k NTU «XPI». Se-riya: Strategichne upravlinnya, upravlinnya portfelyamy`, programamy` ta proekta-my`. Kharkiv: NTU «hPPI», 2017, vol. 2 (1224), pp. 17-22. 
25. Il'juk, V.V. Metodologicheskij podhod k upravleniju stejkholde-rami innovacionnyh proektov [Methodological Approach to Stakeholder Management of Innovative Projects]. Organizator proizvodstva. 2016, no. 4, pp. 38 - 55.

26. Try`fonov, A.Y`., Docenko, N.V. Rozraxunok klyuchovy`x pokazny`kiv modeli ASC dlya vy'-znachennya vzayemodiyi stejkxolderiv $v$ innovacijnomu proekti [Calculation of ASC Model Key Indicators for stakeholder engagement in an innovation project]. Komunal ne gospodarstvo mist. 2019, vol.3 (149), pp. 91 - 98

27. Try fonov, A.Y.. Docenko, N.V. Rozrobka modeli dlya analizu vzayemodiyi stejkxolderiv innovacijnogo proektu [Development of a model for analyzing the stakeholder interaction of an innovation project]. Vcheni zapy `sky' Tavrijs `kogo nacional’nogo universy `tetu im. V.I. Vernads`kogo. 2019, vol. 30 (69), no 2, pp. 220225.

28. Remeshevs`ka I. V., Gurecz` N. V. Identy`fikaciya stejkxolderiv proektiv vprovadzhennya sy`stemy` ekologichnogo menedzhmentu u municy'pal'ny`x utvorennyax [Identification of stakeholders in projects of implementation of environmental management system in municipalities]. Strategichne upravlinnya, upravlinnya portfe-lyamy`, programamy` ta proektamy`. 2019,no. 1 (1326), pp. 63-70.

Надійшла до редакції 00.00.2019, розглянута на редколегії 00.00.2019

\section{Анализ существующих моделей и инструментов управления стейкхолдерами проекта}

Проанализированы существующие инструменты и модели управления заинтересованными сторонами проекта. Известно, что эффективное взаимодействие со стейкхолдерами положительно влияет на различные аспекты управления проектом. В статье акцентируется внимание на необходимости стейкхолдеранализа как неотъемлемой части проекта. Большой интерес к данной тематике связан с тем, что лучшие результаты деятельности показывают организации, которые в процессе своей работы создают ценность для всех стейкхолдеров. Известно, что в пятом издании стандарта Института управления проектами PMBoK, - управление заинтересованными сторонами было выделено в новую самостоятельную отрасль знаний по управлению проектами. Сегодня существующие методы и модели предназначены для уровня исполнителей: руководители проекта, руководящая команда, специалисты офисов. Но для верхних эшелонов власти и управления бизнесом соответствующие модели и методы управления практически отсутствуют. Но это уровень принятия стратегических решений, от которого зависит около $50 \%$ успеха проектной деятельности. В статье рассмотрены теоретико-методические подходы и модели стейкхолдер-анализа, позволяющие идентифицировать, оценить характеристики важности, силы, актуальности заинтересованных сторон и в зависимости от этого наметить стратегию управления взаимодействием с ними. Сделан вывод о том, что существующие методы, как правило, рассматривают взаимоотношения заинтересованных сторон и компаний, но не учитывают специфику проекта. Проанализированые модели и инструменты условно можно разделить на 3 категории: количественные, качественные и комплексные. Количественные модели генерируют числовые данные, которые можно превратить в числа. Качественные модели производят нечисловые данные (визуализация). Комплексные - объединяют в себе несколько качественных и количественных моделей, или является их комбинацией. Кро- 
ме того, количественные модели часто являются сложными математическими комплексами, которые можно применять только в составе автоматизированной вычислительной системе.

Таким образом, разработка эффективных методов управления заинтересованными сторонами в проектах и программах является актуальной задачей.

Ключевые слова: заинтересованная сторона, проект, метод, модель, инструмент, взаимодействие стейкхолдеров.

\section{Analysis of Existing Models and Instruments of Project Stakeholder Management}

The existing tools and models for managing stakeholders of the project are analyzed. It is known that effective interaction with stakeholders positively affects on various aspects of project management. The article focuses on the need for stakeholder analysis as an integral part of the project. Great interest in this topic is related to the fact that the best results are shown by organizations that in the course of their work create value for all stakeholders. It is known that in the fifth edition of the PMBoK standard, stakeholder management was highlighted as a new independent branch of project management knowledge. Today, existing methods are intended for the level of contractors: project managers, management team, office professionals. But for the upper echelons of power there are no relevant management models. But this is the level of strategic decisions, on which about $50 \%$ of the success depends on.

The article discusses theoretical and methodological approaches and stakeholder analysis models that allow to identify, evaluate the characteristics of the importance, strength, relevance of stakeholders and, depending on this, outline a strategy for managing interaction with them. It is concluded that existing methods, as a rule, consider the relationship between stakeholders and companies, but do not take into account the specifics of the project. Analyzed models and tools can be divided into 3 categories: quantitative, qualitative and complex. Quantitative models generate numerical data that can be converted to numbers. Qualitative models produce nonnumerical data (visualization). Comprehensive - Combine several qualitative and quantitative models, or a combination of them. In addition, quantitative models are often complex tools that can only be used as part of an automated computing system.

Thus, the development of effective methods for managing stakeholders in projects and programs is an urgent task.

Keywords: stakeholder, project, method, model, tool, stakeholder interaction.

\section{Відомості про авторів:}

Трифонова Альона Ігорівна - аспірант кафедри менеджменту, Національного аерокосмічного університету ім. М.Є. Жуковського «Харківський авіаційний інститут» E-mail - alona.igorevna@gmail.com, ORCID: 0000-0002-3798-9639.

\section{About the authors:}

Tryfonova Alona - post-graduate student of the Management Department, National Aerospace University named after M. Ye. Zhukovsky "Kharkiv Aviation Institute", Kharkiv, Ukraine, alona.igorevna@gmail.com, ORCID: 0000-0002-3798-9639 